\title{
Resenha
}

\section{The Power of Tolerance: A Debate (Wendy Brown e Rainer Forst, 2014).}

O livro The Power of Tolerance é resultado de um debate entre Wendy Brown e Rainer Forst realizado no dia 08 de dezembro de 2008 no Institute for Cultural Inquiry, em Berlim, no âmbito da série Spannungsübungen. Foi proposto pelos organizadores (Antke Engel, que conduziu o debate, e Christoph Holzhey e Luca Di Blasi, autores do epílogo que compõe o livro) que Brown e Forst debatessem três temas. $\mathrm{O}$ primeiro relacionado à constituição do objeto: como a tolerância realmente constitui subjetividades específicas daqueles que toleram e dos que são tolerados? O segundo relativo ao conflito inerente ao tema: até que ponto e como o conflito pode ser entendido enquanto uma tensão produtiva? E o terceiro, focado no papel do Estado, propôs uma reflexão que, ao considerar a tolerância como discurso de governabilidade, questionasse até que ponto a tolerância despolitiza o campo social. O livro apresenta a fala de Wendy Brown e Rainer Forst, suas respostas à audiência e ao debatedor, e conta também com um epílogo dos organizadores que reflete sobre a noção de tolerância

\footnotetext{
${ }^{1}$ Doutora em Ciências Sociais pela Universidade Estadual de Campinas (Unicamp), pesquisadora do Núcleo de Estudos de Políticas Públicas (NEPPs) da Universidade Estadual Paulista (Unesp) e professora na Universidade Anhembi Morumbi (SP). Contato: camilagdemario@gmail.com.
} 
e, para além do debate, sobre o entendimento teórico de ambos acerca do tema.

As ideias apresentadas pelos autores no debate que compõe o livro baseiam-se nos livros Regulating Aversion: Tolerance in the Age of Identity and Empire de Wendy Brown e Toleranz im Konflikt (Toleration in Conflict, na versão em inglês) de Rainer Forst. Ambos possuem importantes contribuições que atualizam o debate sobre a tolerância e partem de pontos de partida teóricos distintos. ${ }^{2}$ Podemos dizer que a riqueza do debate apresentado neste livro está essencialmente em romper a barreira com o debate foucaultiano no caso de Brown, e com o debate habermasiano no caso de Forst. Alerto que é preciso que nossa análise evite reduzir os autores a essas duas perspectivas, bem como pensar que Brown é contrária à tolerância e Forst favorável. Trata-se como veremos de preocupações analíticas e metodológicas distintas e orientadas por diferentes perspectivas teóricas, porém no campo da teoria crítica. Mas, como argumentam os próprios autores, são análises complementares que nos oferecem pistas para o entendimento das relações de poder e dominação visando a construção de democracias justas.

Apresentarei aqui os argumentos centrais de ambos os autores e buscarei ao final apontar para algumas questões oriundas do debate.

A oportunidade de escrever essa resenha vem em um momento em que esse debate se faz mais do que necessário. Especificamente no contexto brasileiro desde 2013 estamos vivenciando uma onda de ódio e intolerância presente, seja de

\footnotetext{
${ }^{2}$ Wendy Brown, cientista política, é professora no Departamento de Ciência Política da Universidade da Califórnia (Berkeley, EUA), e tem concentrado seu trabalho em análises de teoria política que interrogam sobre as relações de poder, identidade política, subjetividade política e cidadania. Rainer Forst, filósofo político, é professor no Instituto de Ciência Política e no Instituto de Filosofia da Universidade Johann Wolfgang Goethe (Frankfurt/Main, Alemanha), e seu trabalho concentra-se no debate e desenvolvimento das teorias da justiça, com temas como justificação e tolerância.
} 
forma declarada ou velada, nos discursos políticos e nos diferentes âmbitos de nossas relações. É possível citar o discurso de grupos ativistas e think tanks como o Movimento Brasil Livre, o Instituto Ludwig von Mises Brasil, ou o movimento Escola Sem Partido; das manifestações de rua nas quais a multidão expôs posicionamentos (a)políticos binários e reducionistas reavivando e reforçando uma lógica excludente das relações sociais; da mídia que tem se empenhado em realizar uma caça às bruxas punindo os "maus" e fazendo uma limpeza necessária para moralizar nossa política e voltar a fazer o Brasil crescer; no discurso de políticos em campanha e em plenário que usam de argumentos racistas, machistas e misóginos, homofóbicos. Ou através do velho argumento que nos diz que bandido bom é bandido morto, em afronta declarada aos direitos humanos.

Em comum, entre os exemplos que mencionei, temos uma lógica que enseja o ódio e a exclusão do outro - daquele que não pensa como eu - enquanto gramática das relações sociais reavivando um "Brasil: ame ou deixe-o" de outrora, entretanto agora com uma nova roupagem que se manifesta no ódio "viral" aos nordestinos que se alastrou nas redes sociais nas últimas eleições para a Presidência da República; em palavras de ordem que diz aos que são de esquerda: "Vá para Cuba" - aqui com algumas variações e podemos substituir Cuba por Venezuela, Bolívia... É o mecanismo da intolerância funcionando em sua plenitude como orientador do discurso político e das relações sociais. Ou, elaborado de outra forma: trata-se da manifestação do poder inerente ao discurso político da tolerância cuja eficácia é justamente promover a despolitização e naturalização dos conflitos e das diferenças.

Wendy Brown e Rainer Forst iniciam o debate apontando questões centrais da noção de tolerância e seu complexo nexo com o poder, lembrando que essa tende a operar discursivamente como se não tivesse nada a ver com o poder. Suas críticas convergem no entendimento da tolerância como uma atitude de superioridade e uma prática social de dominação; trata-se para ambos de um fenômeno discursivo que materializa tais práticas sociais. 
A tolerância remete a uma relação hierárquica de poder, já que implica em uma relação na qual alguém é quem tolera e outro é o tolerado.

É justamente essa característica que justifica a postura cética de Brown perante a tolerância enquanto um projeto emancipatório. Pois a tolerância mantém as hierarquias entre maiorias e minorias, além de ser uma forma de governo doméstico que cria e regula identidades e também serve de legitimação do imperialismo político cultural do ocidente - tolerância e aqueles que são toleráveis são identificados a partir do ocidente.

Por essa razão Brown argumenta que a tolerância é um instrumento de governo liberal e um discurso de poder que legitima a supremacia ocidental e a violência do Estado. É na dimensão do discurso que Brown centra sua análise, questionando como enquanto discurso de poder a tolerância despolitizou seus efeitos, já que a contínua reprodução do lugar do outro é inerente à estrutura discursiva da tolerância.

Brown constrói sua crítica a Forst remetendo à distinção que o autor faz entre fé e razão. A autora lembra que para Forst a tolerância é necessária porque, antes de mais nada, alguém tem um julgamento negativo sobre o outro, você não gosta ou não acredita nas crenças do outro e seu ato de julgar e tolerar estaria baseado mais na fé do que na razão. Para Brown esse argumento pode até se sustentar quando questões religiosas estão postas em causa, entretanto atualmente o discurso da tolerância refere-se cada vez mais a crenças e práticas que não são religiosas, e estão localizadas cada vez menos no âmbito dessas crenças. Falamos em tolerar coisas, práticas, culturas, sexualidade. Esse discurso implica em práticas sociais excludentes, pois se a pessoa acredita que os homens brancos são superiores e que a heterossexualidade é o natural, automaticamente os árabes e os homossexuais são objeto da tolerância. A questão central que a autora coloca recai sobre o regime normativo de poder, particularmente sobre a tolerância enquanto respeito, estabelecendo um diálogo crítico com Forst.

Brown deixa claro: tolerância funciona como um éthos de respeito ao outro, suas crenças e práticas, apenas no nível da virtude 
individual. Enquanto discurso político que circula do Estado para a sociedade, do indivíduo para a comunidade, ela reproduz práticas excludentes e de dominação ao ter como objetos centrais etnicidades, sexualidades e culturas. Dessa forma, seu trabalho está centrado em mapear "como o discurso contemporâneo da tolerância opera como um poder normativo, e o que suas formas de operar revelam sobre os problemas e questões contemporâneas do poder e do liberalismo" (p. 19). A questão central para ela passa a ser entender como o discurso contemporâneo da tolerância manipula os desafios impostos à cultura hegemônica como se eles fossem diferenças naturalizadas ou desvios anormais.

Rainer Forst, por sua vez, realiza uma análise normativa e conceitual da noção de tolerância, preocupado em buscar o pano de fundo normativo mais adequado para seu entendimento. Ele inicia seu argumento notando que a tolerância pressupõe três componentes: o da objeção; o da aceitação, quando buscamos razões que expliquem por que devemos tolerar crenças que consideramos ruins ou erradas; e o da rejeição, quando se conclui que determinadas crenças ou práticas são tão ruins que não devem ser toleradas. Eis o famoso limite da tolerância (p. 24).

Segundo Forst, o entendimento desses componentes nos permite perceber a perigosa dialética contida no discurso da tolerância: é normal que as pessoas considerem o racismo uma forma de intolerância, ao mesmo tempo percebemos pessoas usando argumentos "raciais" para criticar aqueles que julgam sustentarem preconceitos raciais. "Assim, as pessoas normalmente concluem que devemos ser tolerantes com as outras raças. Até isso é errado, porque significa que você aceita de alguma forma as objeções coladas por um racista contra o outro e apenas pede a ele que tenha razões adicionais para ser tolerante, o que significa pedir para não agir a partir de seus impulsos racistas" (p. 24). Entretanto, nesse caso a postura correta deveria ser lutar contra o racismo. Ou seja, a tolerância nem sempre é a melhor postura perante o intolerante.

A tolerância para Forst pode ser entendida em duas chaves: a da permissão e a do respeito. Na primeira permite-se ao outro 
que ele exista e seja quem deseja ser desde que o faça submetido às suas regras e leis; trata-se de uma relação de tirania, porque a permissão é hierárquica e se baseia em regras arbitrárias. Nesse caso é o soberano ou a maioria quem determina quem deve ser tolerado e o que podem fazer, impedindo aos tolerados que tenham acesso a direitos plenos e iguais.

A dimensão do respeito surge quando uma demanda por justiça política é colocada, o que requer resistir à norma politicamente imposta e questionar sua legitimidade reclamando por justificações razoáveis sobre as regras arbitrárias impostas. Neste ponto do argumento, Forst remete à sua noção de justiça como justificação e à justiça democrática. $\mathrm{O}$ autor argumenta que para entender o discurso político da tolerância e os conflitos por ele gerados é preciso responder o que é um argumento apropriado, e não apenas para a vida privada mas para o reino do político. Ou seja, que precisamos de uma noção de justiça democrática que nos forneça um critério do que é uma boa razão para que possamos construir ou reformar uma instituição e que determine como interpretar os direitos básicos.

Antes de prosseguir, é importante ressaltar que para Forst é fundamental que a estrutura básica da sociedade seja plenamente justificada, e por isso o direito à justificação de demandas é em sua teoria o bem fundamental da justiça. Para ele, mesmo que o processo de justificação das estruturas de poder e distribuição de bens e riqueza possa não fazer frente às injustiças históricas e presentes, ele nos permite alcançar as raízes da injustiça social e estruturar os meios institucionais através dos quais alterá-la. Ou seja, instituições justas forçariam o "melhor argumento" no que se refere à justificação dessa distribuição. Seu ponto de partida normativo é o entendimento da dignidade dos indivíduos como atores, agentes que não devem ser submetidos às estruturas de poder que não podem influenciar.

Sua teoria discursiva da justiça não é puramente procedimental, seu fundamento encontra-se essencialmente em um princípio moral de justificação que requer generalidade e reciprocidade. A noção de reciprocidade contém a ideia de que 
ninguém recusaria a outrem demanda que faria a si mesmo; a de generalidade que as razões para as normas gerais precisam ser compartilhadas por todos que por elas são afetadas. Soma-se a isso a exigência de que o princípio da justificação precisa estar de acordo com os contextos sociais concretos, com a pluralidade de valores éticos e com as várias esferas sociais e comunidades. ${ }^{3}$ Por essa razão, Forst mobiliza os critérios de justiça que estão na base de sua teoria: o da reciprocidade e da generalidade, pois nossos argumentos aos serem públicos e politicamente sustentados devem apresentar-se de acordo com esses critérios. Esse é o porquê de o debate sobre tolerância precisar acontecer no âmbito do político e basear-se na justiça democrática.

Nos termos de Forst, a "arte da tolerância é a arte de achar razões apropriadas" (p. 31), que devem ser apresentadas para as pessoas quando você acredita que elas devam aceitar normas que não estão de acordo com suas práticas e crenças. Isso justamente porque a tolerância sempre esteve ligada ao poder, porque é, e sempre foi, uma prática de dominação, e por reificar identidades e produzir sujeitos disciplinados (p. 31).

O foco de seu argumento está, portanto, nas justificações que devem ser apresentadas às pessoas ao submetê-las às normas, políticas e legais em uma sociedade democrática plural. Para ele, justificar o que se propõe como socialmente legítimo é um desafio a ser encarado do ponto de vista da justiça e da tolerância. Aqueles que entendem que uma objeção não deve transformar-se em uma rejeição porque isso seria injusto são aqueles que mobilizam justiça e tolerância ao mesmo tempo.

Finalizo essa resenha apontando para algumas questões sobre as quais os autores convergem e divergem e que surgem ao longo do debate com a plateia e no epílogo. Como apontei no

\footnotetext{
${ }^{3}$ A ideia de esferas sociais e a noção de comunidade com a qual Forst trabalha é derivada da perspectiva comunitarista de justiça social. Estas noções são melhor trabalhadas pelo autor em trabalho anterior ao que estou me baseando nessa pesquisa, sua tese de doutorado, publicada no Brasil sob o título Contextos da justiça pela Editora Boitempo.
} 
início, os argumentos dos autores são mais complementares do que antagônicos e também por essa razão o debate entre eles gera vários pontos de tensão. Ambos buscam caminhos para resolver a tensão que consideram estar inscrita na noção e no discurso da tolerância: a de que a tolerância oculta, reproduz e estabiliza as desigualdades e a dominação.

Forst adota uma perspectiva mais comunitarista e liberaligualitária, ${ }^{4}$ que é também orientadora de sua teoria da justiça como justificação; enquanto Brown acaba trilhando uma perspectiva mais liberal ao centrar seu argumento na ética e virtude individual.

A diferença, como apontam Holzhey e Di Blasi no epílogo, é que para Forst essa tensão inscrita na noção e no discurso da tolerância, e os conflitos por ela gerados, não são uma característica geral (da tolerância), mas sim de um de seus componentes, o da permissão. Assim, o componente do respeito apresenta uma saída política positiva e viável para a construção da tolerância. Forst aponta ao longo do debate que a tolerância não é um valor em si, mas a justiça sim; e ela é elemento crucial para a justiça. Por isso seu esforço em justificá-la normativamente e demonstrar que a tolerância tem um duplo potencial: o de ser uma prática através da qual é possível aperfeiçoar ou se opor à lei. Já Brown está preocupada em fazer a crítica ao discurso contemporâneo da tolerância e suas formas de violência, o que não implica em ser contra a tolerância. Apesar de a autora manter-se cética com relação ao potencial da tolerância como um projeto político emancipatório, ao distinguir o âmbito político do privado e apresentar a tolerância como uma virtude individual, ela apresenta uma leitura positiva dos potenciais da tolerância enquanto possibilidade de prática ética orientadora das ações cotidianas das pessoas. Brown parece entender a tolerância como um todo tal como Forst entende

\footnotetext{
${ }^{4}$ O liberalismo igualitário é influência da teoria da justiça de John Rawls em seu pensamento claramente presente na busca por justificação e no entendimento sobre qual seria o argumento mais razoável a ser apresentado como justificativa no debate público.
} 
o componente da permissão, daí eles apontarem para caminhos distintos.

Entretanto, durante o debate, Wendy Brown alerta Forst que não crê ser possível pensar a tolerância como crucial para a formulação da justiça, e apresenta uma provocação com a qual encerro: se a tolerância realmente mascara os poderes que produzem as diferenças como conflituosas, então deveríamos dar um passo atrás, estudar esses poderes e buscar por igualdade, e não por tolerância.

\section{Referência}

BROWN, Wendy; FORST, Rainer. The Power of Tolerance: A Debate (ed. Luca Di Blasi; Christoph F. E. Holzhey). New York: Columbia University Press, 2014. 